\title{
Energy Roadmap: Techno-Economic Content and Implementation Issues
}

\author{
Ajupov A.A. ${ }^{a}$ \\ Kurilova A.A.b \\ Anisimova lu.A. ${ }^{c}$ \\ ${ }^{a}$ Kazan Federal University, Institute of Management, Economics and Finance, Kazan, 420008, Russia \\ bcTogliatti State University, Togliatti, 445667, Russia, Email :aakurilova@yandex.ru
}

\section{Doi:10.5901/mjss.2015.v6n1s3p30}

\section{Abstract}

The paper analyses the integration of the economic interests of the countries of Eastern Europe. The main direction of the research is a strategy of creation of a unified energy systems of the countries of Eastern Europe and Russia. The roadmap will enable participants to meet the growing energy consumption and energy security of the participants. Forecasting is the main approach in the development of scenarios for implementing the roadmap. Technical and economic content of the roadmap is based on the joint development of the Russian Agency for the Cooperation of Energy Regulators and ENTSO-E.

Keywords: the energy market, roadmap, the financial instruments.

\section{Introduction}

Currently, the economic interests of Europe aimed at strengthening and improving the system against faults in the supply of energy to the energy problems in a global context through co-operation with partner countries and with international organizations. Energy markets are large-scale mechanism, which is impossible without the existence of supporting institutions. Dani Rodrik (Rodrik, 2014) in his work draws attention to the institution of property rights; judicial Institute, charged with the enforcement of contracts; macroeconomic regulators, smoothing economic cycles; the institute of credit and financial system, providing oversight of financial stability and preventing financial panic; institute of uniform standards in the areas of technical standards, safety and environment; Institute of insurance system, giving some protection from market risks.

According to experts of the energy research Institute of RAS, recent trends indicate the manifestation of a number of factors that lead to instability of energy markets. Table 1 presents the factors affecting the stability of world energy markets.

Table 1: Factors influencing of world energy market

\begin{tabular}{|l|l|}
\hline Factors & The impact on electricity markets \\
\hline $\begin{array}{l}\text { Changing relationships between actors in the } \\
\text { energy markets (consumers and producers) }\end{array}$ & $\begin{array}{l}\text { Not enough effective regulatory instruments of the world energy market has led to changes in the } \\
\text { relationship between actors in the energy markets }\end{array}$ \\
\hline The change in energy consumption & World energy consumption over the last 60 years has increased 5-fold and per capita - in 2 times. \\
\hline $\begin{array}{l}\text { Change of regional proportions of energy } \\
\text { consumption }\end{array}$ & $\begin{array}{l}\text { Regional disparities in energy consumption in the world, with high rates in the developing } \\
\text { countries of Asia and India. }\end{array}$ \\
\hline Energy supply & $\begin{array}{l}\text { The reduction of the volume of hydrocarbon production in developed countries has led to a } \\
\text { reduction in energy supply }\end{array}$ \\
\hline The need for investment & $\begin{array}{l}\text { There is the required amount of capital for the implementation of investment projects } \\
\text { (modernization of the generating facilities and distribution lines), but it is difficult to determine the } \\
\text { level of profitability of investments to offset the risks. }\end{array}$ \\
\hline Rising energy prices & $\begin{array}{l}\text { Since 2000, a steady growth of oil prices - the conflicts in the middle East, extreme weather } \\
\text { conditions, etc. }\end{array}$ \\
\hline International energy trade and infrastructure \\
development & $\begin{array}{l}\text { Supply and consumption of energy in the world through the growth of international energy trade } \\
\text { brought the problem on a global level. }\end{array}$ \\
\hline Supply risk & $\begin{array}{l}\text { The growth in transit conflicts due to the increase in the number of transit countries. The maximum } \\
\text { throughput of individual types of transport. Political conflicts. Natural and man-made disasters. }\end{array}$ \\
\hline
\end{tabular}


Table 1 lists not all the factors that threatens the stability of world energy markets. In the current trend of globalization we should not ignore technical progress, which promotes a mutually beneficial relationship. Taking into account a technical factor we should include its unpredictability.

Independence of energy companies in Russia is limited to the statutory provisions. In European countries, individual consumers cannot buy on the wholesale electricity market of Russia required amount of power. In order to ensure effective cooperation between the Russian energy companies and European consumers is necessary to develop a comprehensible language is the roadmap.

\section{Theory}

The roadmap was used in the 70-ies of the 20th century. (Phaal, 2004). Motorola developed a Road map for expanding market for its products. Many researchers note that the roadmap is a clear sequence of purposeful action in the legal, technical, financial-economic, scientific and humanitarian spheres, ensuring the reduction of energy resources consumption, the replacement of expensive and scarce energy resources for more accessible and improving the efficiency of their use. The features of the preparation and the implementation of the roadmap should be noted:

- the long-term planning based on the development of subprograms;

- the identification of key stages of development are interrelated by the time of their achievement;

- the support of transparency objective information about progress (scientific, technical, economic, financial) for project participants;

- the preparation of implementation options with regard to the possibility of their achievement at different external parameters (e.g., state support) and internal factors (e.g., different capacities of investments). Table 1 presents the mechanism of state regulation of the electricity market.

One of the standards of poorly soluble contradictions is the contradiction between promising high profitability and current insolvency. It is quite often that tomorrow's profitable innovative project does not provide a standard and mandatory payments today, for example, taxes or interest on borrowed resources. Only in the case of a comprehensive consideration of all aspects of the innovation strategy of the company and its financial policy can provide them with high overall efficiency.

Forecasting energy consumption is the basis for developing a roadmap for the future. Over the last decades, world energy consumption has increased by 5 times, and the roadmap will allow the country to meet the growing electricity needs. Electricity suppliers can implement excess reserves and ensure the capacity of generating companies and distribution lines.

Practice of interactions between producers and consumers of energy supply, formed in the last quarter of the twentieth century, is becoming a thing of the past. Table 2 presents the mechanism of state regulation in the European Union and Russia.

Table 2: The Mechanism of state regulation of the energy market

\begin{tabular}{|c|c|}
\hline European Union & Russia \\
\hline $\begin{array}{l}\text { The General management for energy } \\
\text { The subsequent stages of regulation relate to the level of } \\
\text { individual EU member States, each of which can operate } \\
\text { different systems of management of the industry. } \\
\text { One regulator power from each EU country members of the } \\
\text { Association of regulators ERGEG (European Regulators' } \\
\text { Group for Electricity and Gas). }\end{array}$ & $\begin{array}{l}\text { The Ministry of energy of the Russian Federation. in formulating and } \\
\text { implementing state policy and normative-legal regulation in the sphere } \\
\text { of fuel and energy complex, including issues of power, the Federal } \\
\text { Antimonopoly service and its territorial bodies. The aim is to ensure } \\
\text { the timely prevention, detection, control and suppression of actions } \\
\text { restricting competition and infringement of interests of subjects of } \\
\text { electric power industry and electricity consumers. }\end{array}$ \\
\hline
\end{tabular}

The information presented in table 2 indicates that the mechanism of state regulation does not weaken, but on the contrary it covers broader areas. Thus, public companies with large reserves, strive to develop processing and to participate in the equity of transport and distribution networks. In turn, large corporations, under the control of which there are processing facilities, transportation and logistics and distribution fuel resources, carry out a strategy of increasing its resource base.

Integration of economic interests of the partner countries is based on the development and strengthening of mutually beneficial relations and further development. Anyway, all kinds of roadmaps in the enterprise form the information base for management through strategic planning. 
One of the main advantages of forming technology roadmaps is involvement in the development of the widest range of specialists of different profiles: developers of new technology or product, marketing specialist, producers, financiers and suppliers. That is the very participation in the development of the roadmap is considered as the influence of management that allows everyone to understand their role in implementing the development strategy of the enterprise, to hear (and see in figures and graphs) points of view and motivations of professionals of other services.

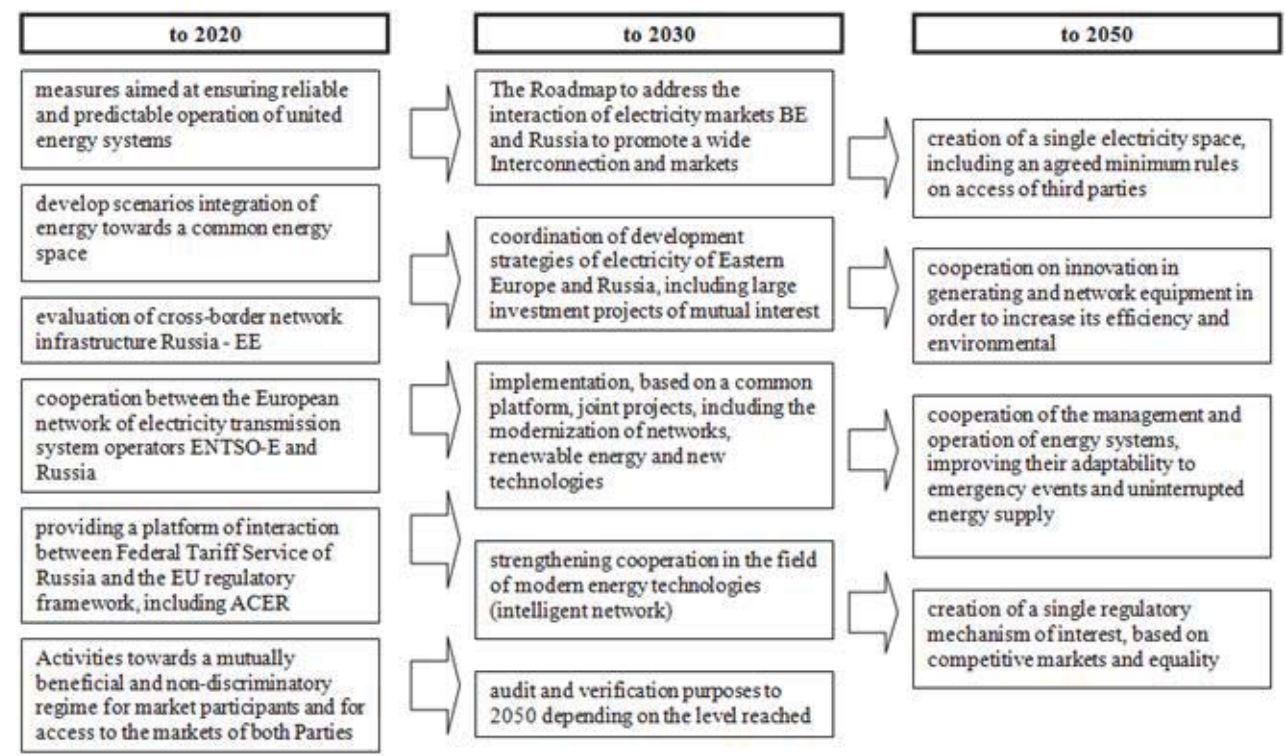

Figure 1. Recommendations and key stages of the Energy Strategy

\section{Results}

A unified approach to understanding the energy issue will allow to develop an effective set of measures for the implementation of the roadmap. So, at the UN Conference on climate change in December 2011, in Durban, 195 participants of the Convention on climate change agreed on a roadmap in re the development of the legislative framework until 2015 for action by all countries. Starting from the period of Bretton-Wood agreement, trade relations between the two countries has changed from simple trade to deep integration. Not a minor role is played by the World trade organization in the development and regulation of trade relations and on the electricity markets.

With this aim, the EU plans to stimulate further the development of well-functioning infrastructure and wholesale markets; to promote consumer participation, including the deployment of smart grids and metering systems (smart grids and meters) and the development of services for flexible demand management; the introduction of drives and maneuvering generation, stimulating decarburization. In this case, you must pay attention to the experience of the existing EU infrastructure markets Nord Pool, The Nordic Power Exchange, OMEL, European Energy Exchange, The International Petroleum Exchange, the Amsterdam Power Exchange.

The roadmap will allow consumer memebers to meet the growing electricity demand, and suppliers to implement excess reserves and to ensure the capacity of generating companies and distribution lines.

European consumers are interested in modernization of the Russian energy system. This situation is explained by the fact that the EU is supplied $88 \%$ of the total amount of oil exports from Russia, $70 \%$ of the total volume of gas and $50 \%$ of the total export of coal. The volume of electricity consumption in 2010 amounted to 16.8 billion kWh [3] currently, companies Bulgaria, Germany, Greece, Italy and the Czech Republic have expressed their interest in cooperation in the field of electric power transmission and energy.

The main goals and objectives of the roadmap up to 2020 are presented in figure 2. 


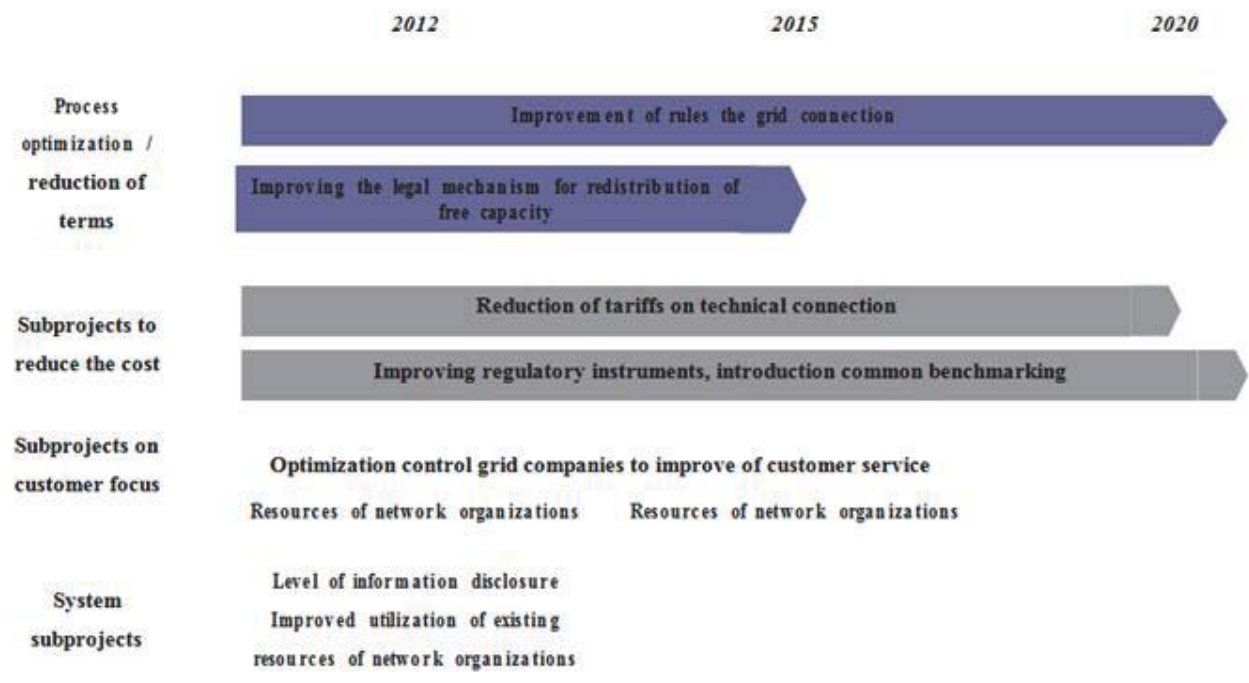

Figure 2. Results of Roadmap 2012-2020

The importance of energy security also requires modification of the relations of the partner countries of the EU and Russia in the field of energy transition from purely commercial relations «supplier-consumer» relationship, based largely on technology.

\section{Conclusions}

Antimonopoly services concern regulation and identify evidence of abuse of market power by companies to their economic status. The manipulation of prices for electric energy can occur by performing economically and (or) technologically unjustified actions, including the exclusive use of participants (including temporary) position on the wholesale market price zones of the wholesale market), which lead to a significant change of prices (price) for electric power.

As a rule, the manipulation is expressed in filing the members overstated (understated) prices within the price bids or withdraw ling of capacity from the market and creating artificial scarcity.

It is important to pay attention to the following factors that contribute to the implementation of the Road map:

- the development of a unified technical regulations - definition of rules of technological connection to switchgear stations, determining relationship of adjacent network organizations, regulation of a procedure of disconnecting from the network;

- the study of the mechanism imputed bets on technical connection;

- the improvement and implementation of standards for information disclosure network companies;

- the introduction of uniform standards of customer service network organizations;

- the improvement and implementation of the mechanism regulating lost income.

Technical and economic content of the roadmap is based on the joint development of the Russian Agency for the Cooperation of Energy Regulators and ENTSO-E.

\section{References}

Groenveld, P. Roadmapping integrates business and technology // Research-Technology Management, 50 (6), 2007. pp. 49-58.

Kogan, Y.M. Modern problems of forecasting electricity demand // Proceedings of the meeting number 59 of the seminar 'Economic Problems of the energy complex', 2006.

Petrick, I.J. and Martinelli, R. Driving disruptive innovation - problem finding and strategy setting in an uncertain world // ResearchTechnology Management, 55 (6), 2012. pp. 49-57.

Phaal, R. Technology roadmapping // Foresight methodologies text book, United Nations Industrial Development Organization (UNIDO) Technology ForeSight Initiative, 2004. pp. 129-151.

Phaal, R., Farrukh, C.J.P. and Probert, D.R. Fast-Start Technology Roadmapping // 9th International Conference on Management of Technology (IAMOT 2000), 21-25th February 2000, Miami. Published in Khalil, T.M., Lefebvre, L.A. and Mason, R.M. (Ed.) 
(2001), Management of technology: the key to prosperity in the third millennium, Selected papers from IAMOT 2000, Pergamon Press, Amsterdam, pp. 275

Phaal, R., Simonse, L. and van Ouden, E. Next generation roadmapping for innovation planning // International Journal of Technology Intelligence and Planning, 4 (2), 2008. pp. 135-152. -284.

Bolotov, I., Čajka, R., Gajduskova, K. The Economic Balance of the Czech Republic and Slovakia During the Economic Crisis // Prague economic papers: quarterly journal of economic theory and policy. . sv. 22, č. 4, 2013. pp. 504-523.

Uspenskaya, I.G. Modern problems of forecasting energy region // Journal 'Problems of Forecasting', vol. 5, 2009. pp. 120-133.

Valitov, Sh.M.,Tufetulov, A.M.,Yartiev, A.F. (2012). Effect of crude quality on crude oil refining efficiency. Neftyanoe Khozyaistvo - Oil Industry, (12), pp. 132-135.

Ibragimov M., Tufetulov A.M. Income distribution and market demand: the case of heterogeneous preferences // Mediterranean Journal of Social Sciences vol. 5 № 24, November 2014, pp. 185-187

NordPool - www.nordpoolspot.com. Data - 20.06.2014.

European Energy Exchange - www.eex.com. Data - 20.06.2014.

Amsterdam Power Exchange - www.apx.nl. Data - 20.06.2014.

The World Bank - http://www.worldbank.org. Data - 20.06.2014. 